\title{
Lessons From Transitional Reforms: What Are The Fundamentals For Successful Transformation?
}

\author{
Richard O. Omotoye, Virginia State University, USA
}

\begin{abstract}
After more than two decades of enduring global reforms, the current paper makes an attempt to investigate the fundamental prerequisites of a successful reform program. The study is particularly complicated by the ambiguity surrounding the very subject matter. While most scholars are united in the view that in order to facilitate a successful transitional process, transitional economies must execute fundamental grassroots reforms, there is no formally accepted universal blueprint of what is considered to be an acceptable transitional program. In an effort to broaden the scope of the investigation, the author probes into neoclassical economic thinking and examines 'conventional reform indicators' commonly associated with successful reforms. But the quest brings the author to the realization that mainstream neoclassical economic thinking by itself is not sufficient; it leaves behind unanswered fundamental questions which - for the sake of methodological and pragmatic necessity-demands resolution. Consequently, the author excavates beneath superficial philosophical thinking, and probes 'mainstream theories' for answers to valid problems confronting transitioning economies. The inquiry is not only beneficial for knowledge, but has implications for policy-making. The paper is sectioned into four parts: introduction is an appraisal of conventional thinking; section II examines reform pre-requisites and pragmatic questions; section III is an attempt to suggest answers to questions prompted in section II and rationalize unequal reform outcomes in reforming societies that execute identical reform program; the concluding section synchronously weaves together the different pieces and ideas by drawing attention on the uniqueness of contemporary reforms and lessons learned from past reforms.
\end{abstract}

Keywords: Transitional Reform; Transitional Economy; Reform Program; Reform Indicators; Sustainable Reform; Structural Adjustment Programs (SAP); Emerging Market Economies (EMEs); Sub-Saharan Africa (SSA); Perestroika $^{1}$

\section{INTRODUCTION}

\section{1. 'Transitional Reform' and 'Transitional Economy' Defined}

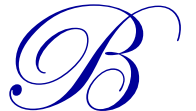

$y$ 'transitional reform' in current paper, the author is alluding to all necessary adjustments that a nation must make to its institutions, core values and practices for the purpose of creating an enabling environment conducive for economic growth and development. The same position was earlier taken by reform economists like Havrylyshyn and McGettigan, who, in their 1999 IMF study (Havrylyshyn \& McGettigan, 1999), concluded that transitional economies cannot successfully transform without first instituting grassroots and institutional reforms for the purpose of creating a reform-enabling environment.

While the author of current paper does not disagree with conventional understanding that describes a "transitional economy as an economy in transformation from a centrally planned to a free-market system" (Feige, 1994), the author explores a little further by investigating the dynamic processes that actually drive the transformation process. In line with this approach, the author subscribes to the view that an economy in transition is an economy undergoing a

\footnotetext{
1 "Perestroika" - a Russian word that means "restructuring", and which has become accepted into English language, refers to the program instituted by the last leader of the former Soviet Union, Mikhail Gorbachev, in the mid-1980s, in an attempt to restructure the soviet economy and improve its competitiveness against western economies. Ironically, the policies exposed the fundamental weakness of the soviet economy, and touched off a wave of social discontent and unrest that eventually culminated in the break-up of the Soviet Union in 1991.
} 
systemic overhaul in its grassroots institutions and support threshold - consisting of economic, financial and social institutions, physical infrastructure, core social and cultural values, and other foundational constituents - all of which have to be restructured to enable the economy to attain full functionality and sustainability in the environment of a newly formed order. Stated in a more pragmatic sense, it is an economy whose underlying substructures are undergoing a systemic transformation - the outcome of which holds the key to resolution of FIVE $^{2}$ fundamental questions facing every economy, specifically: (1) What goods and services should be produced? (2) How should the goods and services be produced? (3) How should the goods and services produced be distributed? (4) How should resources be allocated in producing those goods and services? and (5) How will the system accommodate change?

Though the context of each stated question is subject to alternative interpretations by different scholars, depending on scholarly inclination and philosophical predisposition, in general, the approach taken in current paper, aimed at investigating the global transitional reform process, is congruent with long-standing methodological approach in economic theory, which require that economic problems be empirically investigated against the backdrop of events being studied. This method of scientific inquiry relies on the acceptance of validity of knowledge, based on experiential learning that provides empirical evidence in support or repudiation of a stated observation. Among authors in mainstream literature that are known to have favored this approach are Adam Smith, considered to be the father of macroeconomics in his "Wealth of Nations", (Smith A., 1776); also in contemporary times, Brue and co-authors (Brue, et al, 2011), and many others. Scholarly studies on transitional reform which empirically investigated issues in economic transformation, based on reform experience in investigated economies include Asad Alam et al. (2008), Mitra (2002), and Havrylyshyn and McGettigan (1999), some of which have already been referenced elsewhere in current paper. Even though none of the mentioned studies specifically addressed the fundamental questions raised earlier in current paper, similar to the approach taken in current study, they investigated reform experiences in transitional economies, examined similarities and dissimilarities in national reform programs, suggested benchmarks for measuring reform progress and performance, and concluded with practical suggestions for policy implementation.

Stated along the common thread of ideas found in above-referenced studies, the view in current paper is that a transitional economy is an economy that is undergoing a systemic transformation from a centrally-planned to a marketbased system, where answers to above-stated fundamental questions were, in the past, decided through stateadministered programs, but today - following almost three decades of validated results from accumulated global reform experiences - the answers are being decided through market-induced and reform-based outcome.

\subsection{Past Works on Transitional Reforms}

The current study does acknowledge past scholarly contributions on the subject of 'transitional economy', many of which were useful in providing a needed guidepost in the research effort. Moreover, the mix of philosophical influences sourced from them, ranging from neo-classical to contemporary Keynesian economic thinking, in many ways, helped to foster the conceptual thinking leading to the paper.

The listing of past studies helpful in current research effort include Edgar Feige (1994), who recognized that transformation is one of the most compelling and challenging issues facing any nation in transition, since it requires a fundamental restructuring of economic, political, social, and legal institutions, as well as physical infrastructure. Feige understood the importance of institutional restructuring at the grassroots level, without which sustained transitional reforms cannot be successfully carried out. In another study which investigated Russia's reforms, Marshall Goldman (1994) concluded that, for the most part, infrastructural mismatch and systemic inconsistencies prevented Russia from producing bold results, comparable to those that can be found in other reforming Eastern and Central European nations. According to him, Russia's transition to a full-fledge market economy will not be complete until its network of grassroots infrastructure and property right laws are brought in line with market-determined forces. Along a similar line of inquiry, Gregory and Stuart (Gregory \& Stuart, 2001), attributed, among other things, the failure of Russia's "perestroika" to the following: (1) internally generated inconsistencies fueled by contradictions between pre-reform institutions and executed reforms; (2) "timing and complementarity", driving the wrongful perception that enterprise

\footnotetext{
${ }^{2}$ In modern times, especially following the upsurge in global transition from centrally-planned to market-based economies, on justifiable ground, an additional/fifth fundamental economic question, namely, "how a transitional economy will accommodate change", has attracted the attention of economists, thus expanding and adding to the scope of "fundamental questions facing every economy".
} 
decision-making process and results were going to actualize almost simultaneously; (3) the resource allocation mechanism that was supposed to support market reforms lacked market incentives and still echoed pre-existing command system; (4) bureaucratic resistance fueled by fear for loss of control by the political ruling class. The authors concluded that Russia's transition to a full-fledge market system will not fully actualize until the country addresses the systemic flaws and chaos from its past which continue to hinder performance at grassroots and institutional levels. In another attempt, Havrylyshyn and McGettigan, in their 1999 IMF working paper (Havrylyshyn \& McGettigan, 1999), reviewed a sample of studies by scholars on privatization experiences in transition countries, and ranked enterprise performance in selected countries and firms by reform outcome, using study-designed benchmark performance indicators. According to them, among the newly privatized enterprises, de novo firms ${ }^{3}$ ranked highest as the best performers, closely followed by outsider-dominated enterprises ${ }^{4}$, and next followed by insider-dominated enterprises $^{5}$, which ranked the least-performing. The authors attributed the success of privatization efforts to providing a suitable market environment for successful development of the private sector. According to them, it is not only the implementation of a well-designed privatization program that is important, but instituting an appropriate enabling environment.

In another similar inquiry in 2002, the World Bank commissioned a comprehensive study that investigated a decadelong experience of reforms in Eastern Europe and former Soviet Union (Mitra, et al., 2002). In the report which provided an elaborate insight into performance, institutional challenges, and systemic constraints facing reform efforts, the authors concluded that while initial conditions are important, reforming nations also need to create threshold institutions that support reforms. According to the study, the transformation landscape in Eastern Europe and former Soviet Union was largely uneven, with the outcome for the most part depending on a mix of threshold conditions created by transforming nations - i.e. liberalization and sacrificial choices made by them, economic and political conditions fostered, etc. In another parallel World Bank study, Asad Alam and co-authors (Alam, A., et. al., 2008), investigated productivity gains in former soviet states, and cited key drivers of productivity growth as investments in infrastructure, reallocation of resources from state-supported subsidized enterprises to market-driven ones, and an improved business environment. The authors also observed that resources did not begin to shift to higher productivity uses until there was a change in economic and institutional incentives. As firms progressively began to utilize their excess labor and capital, which had been idle during years of transitional recession, and realigned resources along market-determined incentives, they began to experience output and productivity increases.

All the studies referenced above addressed typical institutional and practical questions that reforming nations must address to enable them successfully transform. They range in diversity and complexity from theoretical to policy and pragmatic issues, and included the following: privatization of state-supported enterprises, implementation of reforms at grassroots level, institutionalization of implemented reforms, liberalization of economic resources along marketdetermined principles, institutionalization and enforcement of private property laws, and other reform needs. The investigations provided a needed guidepost for current study.

\subsection{Uniqueness of Study}

Even though the above-mentioned studies underscore the inclination in current paper, aimed at underlining the role played by grassroots and institutional reforms in the social and economic transformation process, they did not adequately address the coherence and completeness of questions pertaining to reforms. There is the need in economic reform literature to identify key reform-associable attributes which a transitional society must possess in order for it to be viewed as truly treading the trajectory of transition from non-market to a market-based economy. The need to fill this void gives emphasis to the current study and underscore the uniqueness of approach taken by its author.

\footnotetext{
${ }^{3}$ De novo firms are the newly formed enterprises, established as a result of transitional reform efforts and are operated along market-determined incentives.

${ }^{4}$ These are firms that are domestically operated in a transitional economy but are owned by an overseas conglomerate or affiliate. While they are generally western firms operated along market-established rules, many of them have a hard time in adjusting to the climate of political instability and economic uncertainty associated with a reform environment.

${ }^{5}$ For the most part, these enterprises are remnants of pre-existing stated-owned enterprises or are owned and operated by politically-connected, influential individuals. Since many of these firms still continue to be state-supported, compared to other firms, their adjustment process to market reform is generally slower.
} 
The paper is, therefore, unique in following respects. First, the grassroots approach in paper, aimed at probing the componential fabrics and substructure that underlie societies and drive tendencies and events in them, is useful for understanding the dynamics of transitional reforms and their transformation process and outcome. Second, the attempt in paper, aimed at clarifying delusions surrounding inequalities of reform outcomes in reforming societies brings additional enlightenment to the reform subject. Citing reform experiences from nations across the globe, the author argues that nations which sacrificially commit themselves to fundamental grassroots reforms and follow through with institutionalization are almost always predictably associated with sustainable and steady reform outcome, while on the contrary, societies that hesitate to make needed sacrificial adjustments always suffer irregular reform outcome. For example, South-east Asian nations did not quite begin to actualize steady reform outcome and economic growth until the region-wide financial crisis of late 1990s, which not only served the purpose of exposing its vulnerability as a region, but also became quite instrumental for building resilience into grassroots reform efforts there. On the other hand, reforms in Africa and many Latin American countries continue to yield unsteady results - given the hesitation by policy-makers in those regions to make needed sacrificial reforms. Third, the study helps to draw the attention of policy-makers and scholars to substantive pragmatic issues involved in the global reform/transformation process (i.e. the evolvement stages of reforms and their inevitability, quality and depth of reforms, the institutionalization process, etc.). Fourth, in addition to many other sources of scholarly contributions that helped to guide the study, the paper draws scholarly roots from reform studies that were either directly or indirectly commissioned by the world's leading multilateral agencies considered to be in the forefront of global reform studies and reform advocacy initiatives in reforming nations - notably, International Monetary Fund (IMF), World Bank, and European Bank for Reconstruction and Development (EBRD). Prominent studies done by mentioned agencies which provided useful guidance in current research effort include Saleh Nsouli (IMF, 1999), Alam, A., et. al. (World Bank, 2008), Mitra, P., et al. (World Bank, 2002), Mitra, P. (IMF, 2002), and many others. Sourcing research ideas and information in current paper from the leading multilateral agencies that advocate and fund reform initiatives around the world was not only helpful in providing a nourishing source of intellectual feed for the research effort, but it also helped to strengthen the authoritativeness and practical relevance of ideas articulated in the paper.

\section{PREREQUISITES OF SUSTAINABLE TRANSITION}

\subsection{Conventional Thinking Driving Global Reforms}

More than two decades after dissolution of the former Soviet Union and soviet-styled command system, the global economy is still adjusting to a historical transition aftermath, as transitioning countries struggle to balance structural equilibrium with market efficiency. Today, virtually, all formerly centrally planned economies, except for North Korea, are in different stages of transition.

But while the universal acceptance of market-oriented reforms on a global scale has created historic opportunities for better management of world's limited resources, it has also prompted the quest for an acceptable transitional platform - and with that - an impulsive urge or tendency to want to embrace a standardized, one-size-fits-all transitional strategy for all reforming societies, even when huge disparities are known to exist in those societies. In this regard, 'Washington Consensus ' - a radical type, standardized reform consensus, supported by western neo-classical scholars and IMF economic theorists which advocate bold market reforms in transitional economies around the world - gradually evolved into universal acceptance as a mainstream reform blueprint. Until the mid-1990s when global structural adjustment initiatives (particularly focusing on the Latin American region) hit a major road block, the 'Washington Consensus' was globally viewed as the standard universal 'recipe' for countries transitioning from centrally-planned to a market-based system. Originally designed for Latin American countries in mid-1980s and later repackaged for Poland, Hungary, and the COMECON countries ${ }^{6}$, 'Washington Consensus' advocated series of "radical shock therapies", aimed at reducing macroeconomic imbalance, and achieving equilibrium and selfsustenance in reforming economies. It was fundamentally built on neoclassical economic philosophy that advocated improvement in three key areas of the economy, namely: macroeconomic discipline; open trade/foreign direct

\footnotetext{
${ }^{6}$ The Council for Mutual Economic Assistance (also known as CMEA), 1949-1991, was an economic organization, led by the former Soviet Union, which comprised of socialist countries in Eastern Bloc and other regions of the world. It was the Eastern Bloc's reply to the formation of the Organization for European Economic Co-Operation in Western Europe. It was disbanded in 1991 upon the adoption of free-market policies by member-countries.
} 
investment; and market competition. Its support components include fiscal discipline, streamlining subsidies in favor of broad-based expenditure (e.g. infrastructure, healthcare, education, etc.), tax reforms, market-determined exchange rates, privatization of state enterprises, legislated framework for property ownership, and deregulated commercial environment for financial markets, trade, and foreign direct investment.

Critiques - among them, Luciana Díaz Frers of Latin America's Center for International Private Enterprise (CIPE, 2008) - admonish that if at the height of its universal embrace, the so-called 'radical shock therapies' spawned any successes, at all, in reforming nations that implemented them, they were short-lived. He cited that between 1988 and 1997, Latin American countries that adopted it demonstrably enjoyed a brief period of sustainable equilibrium in macro-economic fundamentals, public finances, trade regime, and successfully launched ambitious privatization programs; but the stretch did not last long, being truncated by prolonged turbulence, the severity of which was huge enough to wipe away earlier gains and trigger contagions to other regions. First, the tequila crisis in Mexico in 1995 (Musacchio, 2012), later followed by the currency devaluation in Thailand in 1997 (Lai, 2000), which was believed to have touched off the regional crisis in Southeast Asia; then the financial crunch in Russia (Gonzalos and Damjanovic, 2001), to which, many have also linked to the Brazilian financial crisis (McHale, 2000). Also in recent times, global financial markets have continued to experience recurring contagions in weaker EU member-states (Missio and Watzka, 2011), particularly, Greece, Portugal, and later, Malta - all of which had earlier adopted Washington Consensus-based policies.

Many factors have been blamed for the failure of 'Washington Consensus' and the renewed determination by policymakers in reforming nations to look elsewhere for alternative remedies. Among them, the following: first, the stigma of universal 'one-size-fits all' approach - the reason for which many view the program as being contextually unsuitable for the specific conditions of individual reforming countries, particularly, the lesser developed nations; second, the deliberate failure by official sponsors to acknowledge the significant disparities in preexisting conditions in transitional societies; third, the recipes associated with 'Washington consensus', which many policy-makers consider to be too radical and unrealistic for conditions in transitional societies - given that transitional societies are still in early formative stages of their transition and still lack strong threshold for support; fourth, policy-makers in reforming nations view the proposition with distrust, perceiving it as an attempt by western institutional establishment to impose externally-sourced mismatched ideas, 'lacking in congruence and exit strategies', on weaker nations, and a ruse for getting them to trade their national sovereignty for much needed financial assistance (Frers, 2008).

Today, reform theorists and policy-makers are more knowledgeable and better equipped than before in reform strategies. They are more united in the view that while a reform roadmap is indispensable for successful transformation, given the dissimilarities of circumstances and events in reforming nations, the implementation course and sequence of a reform program (even when generic in design) cannot be exactly identical for all societies; they must reflect the peculiarities and needs facing each reforming nation.

\subsection{Orthodox Economic Thinking}

But what really are the fundamental conditions that must be met in order for a transitional economy to be considered successful, or in the very least, viewed as truly treading the trajectory of transition from non-market to a market-based economy? While scholars are primarily united in the view that structural adjustment reforms are a necessary precondition for successful transition to a market economy, there is no universal consensus regarding a formally accepted blueprint of what constitutes a transitional reform program. While reform scholars - following the surge of postsoviet reforms of mid-1990s - have proposed a wide range of ideas regarding indicators/factors that they view as constituting a successful reform agenda, after more than two decades of enduring universal reforms, they are taking another look - with the view in mind of drawing insightful lessons from the past. Perhaps the most important lesson learnt is that structural adjustment programs (SAPs) cannot be too rigid in design and implementation, but must have sufficient flexibility - given that conditions in reforming societies are not uniform. The contextual dissimilarities can be traced to a range of factors, including the following: unequal experiences benefited from earlier reforms; inequalities in stages of economic development and technological advancement; cultural dissimilarities; unequal historical circumstances; unequally developed socio-political platform and grassroots infrastructures for sustaining reforms; and other types of disparities traceable to pre-existing conditions in reforming societies. 
Notwithstanding though the realization that a universally accepted transitional reform blueprint/program is not within reach, after more than two decades of experiential learning, reform scholars have come to recognize certain distinct attributes that can be associated with reform programs - bearing in mind at the same time the need for structural flexibility that reflect peculiarities in reforming societies. Generally speaking, contemporary thinking behind conventional indicators of reform is driven by the funding priorities of official development agencies - particularly, IMF, EBRD, and other multilateral agencies that advocate for or support reform programs in reforming nations across the globe. In line with priorities of the mentioned agencies, traditional reform indicators are geared toward the accomplishment of certain core idealistic policy-goals, which usually include the following: economic and financial liberalization; macroeconomic and fiscal stabilization; restructuring and privatization; strong legislature and institutionalization. This economic thinking, which is deeply rooted in neo-classical economic thinking and embraced in the funding priorities of stated agencies, is widespread and well-established in economic literature. Some of the studies in transitional reform that are founded on this line of reasoning have already been mentioned in current work. They include Saleh Nsouli (1999), Alam, A. et al. (2008), Mitra, P., et al. (2002), Mitra, P. (2002), Mitra (2002), Havrylyshyn and McGettigan (1999), and many others.

\section{Liberalization}

Liberalization involves creating an enabling environment in which prices are determined through market mechanism procedures that fosters free competition among private agents and individually-owned resources, and where government intervention, if and when justified to be necessary, is kept to a minimum. The liberalization process helps assure the following: (1) that prices of commodities produced reflect their true cost to the society - simultaneously viewed in light of producer and consumer self-serving interests; (2) that resources are allocated to satisfy the needs most desired by the society; (3) that resources are allocated among alternative needs in the most efficient manner; (4) that government intervention will be considered necessary only in instances when it can be reasonably demonstrated that the pursuit of one party's interests and priorities tends to jeopardize another party's welfare; (5) that price determination through market mechanism is critical for choice-making decisions involving the following actions resource allocation by enterprises, buying and selling decisions by agents, functionality of the domestic market, trade with the outside world, etc.

\section{Macroeconomic and Fiscal Stabilization}

Following price liberalization and market-adjusted cost restructure, it is reasonable to anticipate a period of instability (in the form of inflationary pressure, supply bottle-necks, high unemployment, and other types of volatility) as the economy seeks to adjust to the dynamics of a newly created market environment. The adjustment process is very critical and will determine the direction that the economy will take in the future. While some economists argue that the economy should be allowed to ride the storm and coast only with minimal or, may be in fact, without any type of assistance by the government (Goel \& Saunoris, 2016), others argue that it is critical that government play a proactive role through active monetary and fiscal policy actions (Lin, 2011) in order to ensure "soft landing" and prevent a possible subversion of the adjustment process which can be caused by mass unrest and public uprising. While the author of current paper believes that it is necessary for the economy to find its own bearing and must be able to develop the resilience necessary for adjusting to the new dynamics of the market-place, it is essential that the government provide a "cushion for soft landing" by providing a conducive macroeconomic environment that utilize a range of incentives, including fiscal and monetary policy tools. The discretion and discipline exercised by the government, particularly in fiscal and monetary decisions concerning government budget, money supply, and balance of payments is what really holds the key. While a support that is too liberal will insulate the economy from making needed adjustment, too little support might truncate the structural adjustment process and prevent recovery and long-term sustainability.

\section{Privatization}

Privatization entails transfer of ownership of business entities (i.e. properties, enterprises, and agencies that support commerce) from government control to the private sector-either the business is profit or non-profit oriented. It also involves providing an enabling environment in support of financial markets (the market environment in which shortterm and long-term financial instruments are traded) and financial institutions (commercial banks, credit unions, 
insurance and other financial intermediaries), which in turn support commerce. In view of the huge potential that it has for wealth creation and concentration of power, the privatization process in transitional economies is often riddled with corruption and other problems that can jeopardize successful transition. If not done in a transparent manner, the same government bureaucrats who oversee the sale and transfer process are ultimately the same individuals who will benefit, since they simply sell state-owned and state-controlled parastatals to themselves or their cronies. This is essentially what complicated privatization efforts and continue to delay a successful transitional outcome in Russia and many Eastern European countries.

\section{Strong Legislature and Institutionalization}

Legal and institutional reforms involve establishing an unequivocally supportive legalistic framework consisting of laws, business rules, guidelines, acceptable ethics, and other norms which can be codified into enforceable law and order. The process is what ensures that the transitional restructure and adjustment process is not truncated, but become integrated into mainstream commercial processes and is institutionalized as part of regular, conventional practice. The process helps to assure continuity and predictability of outcomes in commercial transactions, helps to minimize risks in transactions, and fosters incentives for entrepreneurship and risk-taking. A legislative and institutionalized commercial framework also helps to prevent or, in the very least, minimize asymmetric information which often causes adverse selection and moral hazard problems in commercial transactions involving market agents and consumers.

\subsection{Unanswered Questions}

There is no doubt that the mainstream economic philosophies discussed above are helpful in providing a valuable insight for clarity on theories that explain conditions which are considered absolutely essential for successful market reform outcomes; hence, they are viewed by reform theorists and policy practitioners as a guide-post for efforts directed at charting the course of transitional reforms around the globe. But after almost three decades of continuing universal reforms, the following pragmatic questions have emerged, and demand answers:

1. Why is there so much disparity in successes achieved by transitional societies, including accomplishments in societies that implement identical reform programs-for example, China compared with India; or say, countries of Central and Eastern Europe (CEE) compared with Russia and the rest of the former Soviet Union?

2. Why do some nations (e.g. Argentina and Philippines) fail to complete the transitional cycle set in motion by them, while others (including latter-day entrants like South-Korea, Hong-Kong, Singapore, and Taiwan), only joining the pursuit much later, are not only able to successfully come full-circle in their transitional journey, but also succeed in ascending the ranks of newly industrialized nations?

3. Why is it that only a few successfully transformed economies succeed as regional prototypes, capable of sparking contagious, domino-effect regional surge in surrounding nations, while similar transformative experiences in other nations are not easily replicable or transmittable to nations within their regional range of influence? For example, the Japanese economic miracle of the early twentieth century became a very powerful transformative influence, inciting economic growth in the Pacific Rim nations, and China and India in recent times; the recent emergence of Brazil as a middle-class economy has often been traced to its strong historical ties to the west, particularly regional proximity to the US. On the other hand, South Africa has yet to impact regional development in much of sub-Saharan Africa or southern Africa in a profoundly demonstrable manner; also, Haiti-a nation that enjoys the same geographical proximity to the US, pretty much like Brazil-remains the poorest nation in the western hemisphere.

4. Do nations that successfully reform have other common attributes (i.e. attributes different from those identified with orthodox reform theories already discussed above) which are yet to be unearthed and acknowledged in mainstream economic reform literature? 


\section{PROBING BEYOND ORTHODOX ECONOMIC THINKING}

In an effort to answer the above-stated questions, an attempt is made in current paper to probe the threshold of orthodox reform theory earlier examined in paper. The position taken in paper is that inasmuch as societies are not equally endowed in resources, they do not possess equal transformative capacity or respond equally to reform programs; hence, it is not uncommon for the same reform program to return dissimilar results in different societies. While acknowledging that conventional/orthodox factors do play a role in shaping reform outcome, accumulated experience based on continuing global transitional reforms spanning the last two-and-half decades strongly corroborate evidence that a society's transformative/absorptive capacity and its ability to return dividends from a given reform program is determined by many other factors. Recognizing this, an attempt is made below to investigate those other factors (i.e. factors unaccounted for in orthodox literature) that account for unequal reform outcomes in different societies particularly factors that account for unequal reform results in societies that implement similar reform programs.

First is the society's point of entry into a defined reform program. Generally, a society's pre-attained development stage - also simultaneously its point of entry into a defined transitional program — is a very critical factor that plays a crucial role in determining the society's transformational preparedness and ability to return dividends from a given set of reform recipes. The key question is whether the society is still at an embryonic developmental stage - still lacking in discernible substructures for support of transitional reforms, or it already has in place visible, reformenabling infrastructures that can be considered somewhat marginally developed or well-established. Standard reformenabling infrastructures, vital for support of transitional reforms typically consist of the following: (i) a visible, functioning government structure with liberalized policies that support entrepreneurship and flow of commerce; (ii) an established legalistic framework for support of trade and commerce; (iii) a legislative framework for support of property and intellectual rights; (iv) an established network of financial institutions and markets that support transfer of resources between lenders/savers and borrowers/investors in an efficient manner; (v) a financial market system that reward market participants for risks; and others. The fact of the matter is that no good reform agenda - regardless of the promises and prospects it might hold for the future - can be executed without a reasonably grounded support threshold, and every good reform blueprint needs a system of reform-enabling institutions for actualization.

This observation was also made in earlier studies - among them, a 2001 World Bank study which investigated the relationship between aid and African reforms (Devarajan, et al., 2001), and another similar, more recent 2012 study by Rutherford which investigated land reform in Zimbabwe (Rutherford, 2012). According Devarajan and his coresearchers, identical reform programs produce dissimilar results in different societies because reforming societies are not equally endowed in reform-support thresholds - since they are not equally developed institutionally and infrastructurally. With an appropriate support threshold in place, the same reform instrument might generate positive dividends in one society but only to produce contrary results in another society that lack a comparable support threshold. This is illustrated in the two charts provided below, exemplifying the reform experience for three countries in their use of aid. In Figure 1 for Ghana and Uganda, donor aid and policy index rose complementarily as foreign donors increased aid to the two countries, rewarding them for improving their domestic policy improvement-hence foreign aid was instrumental in the success of reforms in the two countries. In Figure 2 for Zambia, on the other hand, donor aid and policy index moved in opposite directions - meaning that donor aid was not accompanied by policy improvement. Given the lack of appropriate domestic policy environment, donor aid did not positively impact reform outcome in Zambia. Thus, while door aid produced results in Ghana and Uganda, it did not in Zambia - given the unequal policy landscape and reform phase in the two groups. Stated in a more pragmatic sense, a potentially effective reform instrument applied at an incongruous phase of a society's transitional journey might not render desired results, and might even become outright counterproductive — as observed in Zambia. 
Figure 1. Aid and Policy in Ghana and Uganda

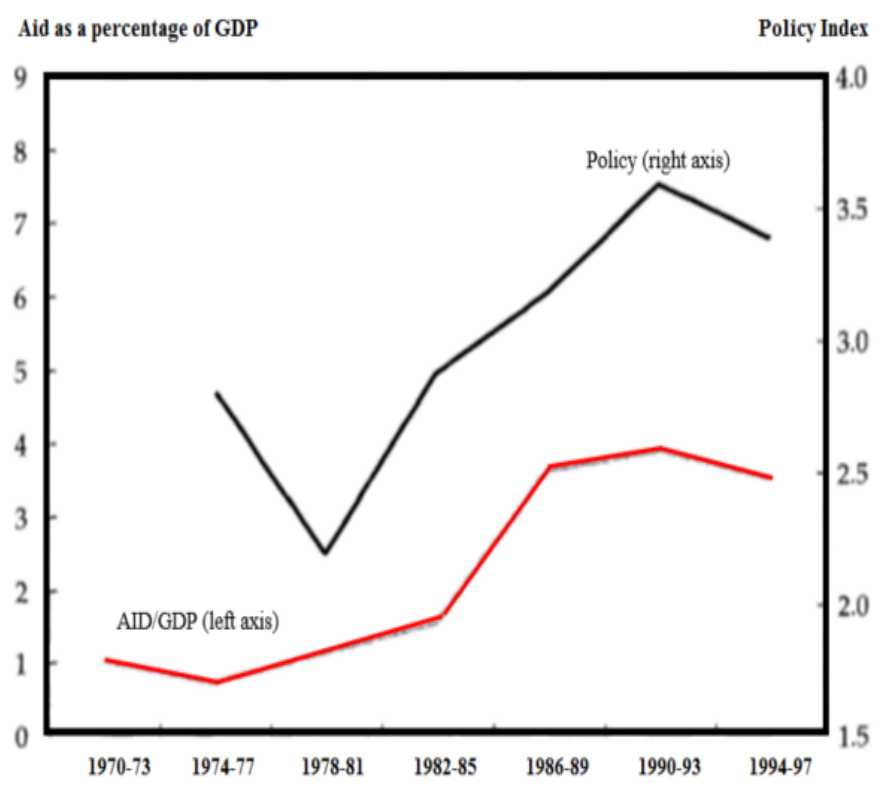

Source: World Bank

Figure 2. Aid and Policy in Zambia

$$
\text { Policy Index Aid as a percentage of GDP }
$$

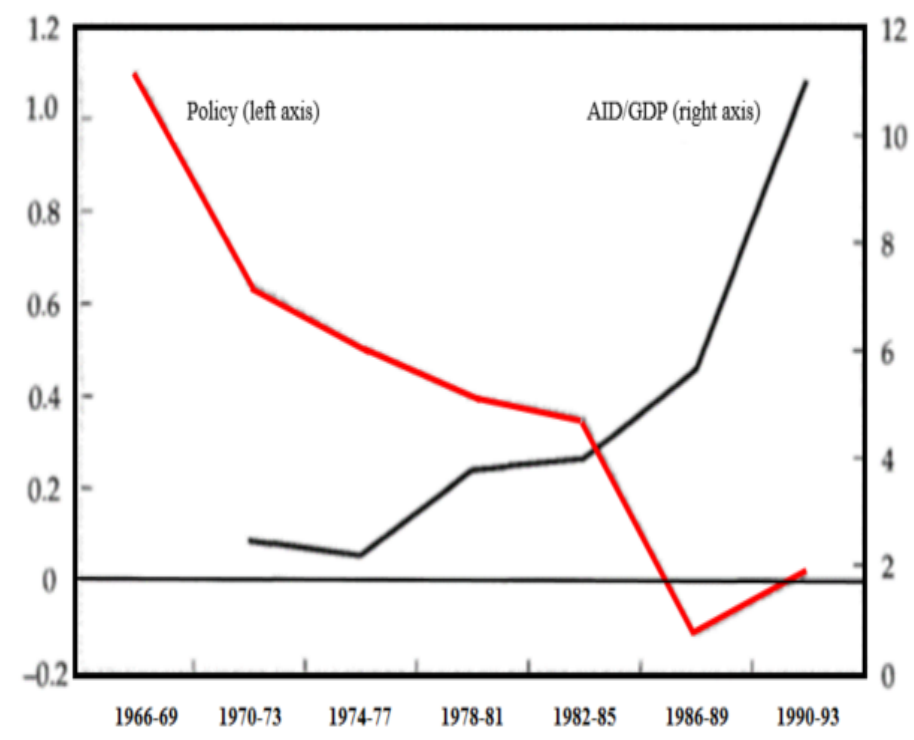

Source: World Bank

A similar finding was also observed by other researchers - among them, Ravallion (2008) and Heidhues and Obare (2011) — who in their empirical studies, investigated unequal reform outcomes from identical IMF SAPs that were applied to regional reforms in China and sub-Saharan African nations. The researchers observed that while market reforms in much of sub-Saharan Africa have been either very slow or completely stalled, parallel reforms in mainland China have produced steady, buoyant results. They traced the contrasting outcomes to the unequal platforms on which 
reforms in both regions were founded. While at the onset of their transitional reforms, most sub-Saharan African nations were still lacking in threshold institutions - needed for support of steady reforms, parallel reforms in mainland China were already founded on a congruent, reform-enabling platform. Furthermore, while in the late 1980s and early 1990s, African nations were just beginning transition from entry-level into formative grassroots reforms, Chinese reforms were already metamorphosing into a settled, institutionalization phase, and were already undergoing transformation from institutionalization to implementation, and were already producing visible, steady results. Given the unequal transitional footing on which reforms in both societies were founded, Chinese and African societies responded differently to similar IMF SAPs. With a firmly established support threshold already in place, Chinese SAPs were selectively applied in support of home-grown reform initiatives that targeted formal and informal sectors, consequently fostering fiscal independence and self-reliance. On the other hand, SAPs in sub-Saharan Africa lacking in reform-enabling substructure institutions — narrowly targeted IMF-dictated conditionality (which consisted of fiscal imbalances and other macroeconomic indicators earlier mentioned in current paper), and noticeably neglected the informal sector-a potentially powerful vehicle for capacity-building. Consequently, unlike in China, IMF-led SAPs in sub-Saharan Africa did not foster domestic capacity-building and were counter-productive. While the same IMF-led SAPs only made its SSA users to become dependent, repetitive users, it fostered capacity-building in China and enabled a sweeping regional transformation in much of Southeast Asia.

Second, similar reform programs failed to produce comparable reform outcomes in reforming societies, given that for a sustained period, there was a prevalent reluctance in official circles to acknowledge the existing disparities in reforming societies' conditions (i.e. political turbulence, level of commitment by the government to execute quality reforms, existing ties fostered with western countries with established market infrastructures, existing regional trade alliances, etc.), hence the longstanding failure to develop individualized reform packages that address the specific needs and unique circumstances of individual reforming countries. The result is the adoption and implementation of standardized resolution recipes for use in reforming countries even when substantial disparities are known to exist in their domestic conditions. CIPE's Luciana Díaz Frers (cited earlier in paper) criticized that "neoclassical ideas failed to generate desired results in Latin America because the policies advocated a one-size-fits-all strategy, designed without regard for individual conditions in reforming countries, and falsely presumed the existence of underlying mechanism that is necessary for functioning market economies" (CIPE, 2005). It is not surprising, therefore, that transitional reforms stalled for decades in some transitional societies (particularly, sub-Saharan Africa, and much of Latin America and the Caribbean), while parallel efforts in others (notably, China, and much of Southeast Asia) paid off.

To further buttress this argument, Gehlbach and Earle (2011) investigated the pace of privatization in Ukraine, basing their study on a sample of 7,000 Ukrainian manufacturing enterprises, many of which were privatized in mid to late 1990s. They uncovered a significant improvement in productivity gains by privatized firms in the far western region, compared to performance by those in the eastern region - attributing the divergence in performance to the relative political calm enjoyed by firms in the far west after the Orange revolution, which was not enjoyed by firms in the eastern region. If a standardized approach could yield dissimilar outcome in a one-country setting, how much more in a multiple-nation and multiple-region context.

Third, lessons spanning more than two decades of continuing global reforms corroborate evidence that societies respond unequally to similar reform programs on account of the unequal settings of their evolvement process (i.e. dissimilarities in the following conditions: resource endowment; historical background; cultural heritage; religious values; and other social factors that are not readily captured in economic models). Understandably therefore, societies are not equally endowed in the formative reform rudiments / fundamentals which are needed for successfully transforming and weaving together an integrative market system. These fundamental reform basics/essentials play a vital role in the reform institutionalization process and particularly in the formation of necessary reform-enabling substructures (i.e. corporate laws, guidelines for privatizing assets and parastatals, capital markets institutionalization procedures, mix of intellectual and property rights legislature, norms for balancing social welfare programs against budgetary expediency, and other rudimentary elements necessary for sustaining a free-market support environment). Thus, in light of disparity in legislative and cultural values, acceptability standards are different, incongruous, and sometimes can be contradictory from society to society. For example, some reforming societies, particularly those from mainstream Islamic culture - on grounds of religious beliefs - still resent bankruptcy laws and marketdetermined interest-based loans, viewing them as contradictory to their religious faith and belief (Awad, et. al., 2010). 
Given their cultural and religious opposition to internationally accepted financial rules, the ability of such societies to tap into mainstream international loans and financial opportunities is severely limited, and invariably, their progress toward transitional reform can be slower.

Fourth, in some societies, particularly, the formerly centrally planned economies that were historically established on anti-market principles, the historically embedded antagonistic sentiments toward market ideas (e.g. acceptability and moral standards concerning individual property ownership rights versus communal ownership, appropriateness and extent of social programs that benefit the underclass population, leverage exercised by the government and methods used in regulating economic growth and instability, etc.) which pre-existed their transitional journey are not going to dissipate overnight. Given their deep-seated cultural obsession with 'idealistic communist values', anti-market sentiments ideologically formed in the course of decades are bound to endure a sustained period of overhang and will continue to resist transitional initiatives aimed at modernization. For this reason, market reforms in Russia and other countries of the former Soviet Union are visibly slower and less progressive, compared to reforms in the Baltics and certain parts of Central and Eastern Europe (Falcetti \& Lysenko, 2005). It is particularly important to underscore that market reforms in the Baltics registered a quicker turnaround, given that central planning was only inertly practiced in the region; it was mixed with informal capitalism and was never really fundamentally instituted to antagonize the market system.

Fifth, there is an increasing empirical evidence to support the view that some societies are more successful than others in the transitional journey, given the pre-existing base of technological endowment already possessed by them-a necessary platform for support and utilization of revolutionary financial market products and methods. Typical financial innovations needed for transitional support in EMs include mobile banking and non-banking financial services facilitated through global telecommunication providers, electronic money transfer services, affordable savings and credit products electronically facilitated through third-party vendors, and other types of financial services designed for extending financial inclusion, but which require some type of soft technology or expertise baseline for support. Utilizing these and other financial tools, some EMs have been able to streamline transactions delivery in stock market, banking and insurance services, and realign their financial sector portfolio delivery in congruence with global standards. In their paper (Salami, et. al., 2012) which focused on comparative benchmarking of growth in the EM economies of Brazil, India, China, South Korea, and South Africa (BICSS), Salami and fellow researchers observed that "acquisition, adaptation and absorption of technical know-how along with strengthening of local technological capabilities" contributed immensely to rapid economic progress in the identified group of countries. Considering that between 2.1 and 2.7 billion adults or approximately 72 percent of adults in the developing world still lack access to basic banking services (G20 Financial Inclusion Experts Group, 2010 Report), efforts directed at deepening financial services and financial inclusion via revolution in electronic and telecommunications technology will go a long way in helping transitional economies successfully reform their banking and financial sector and quicken their pace of transitional reforms.

\section{CONCLUSION}

Compared to reforms that preceded them, the transitional reforms of the last two-and-a-half decades are unique in certain respects. First, they are universal in geographical scope and extent, having either broadly or moderately to an appreciable degree, transformed the entire global economy. Following several decades of "learning by doing" from past reforms, there is an unrelenting upsurge in global reawakening that is compelling for an improvement or outright replacement (as the case may be) of social governance practices, with a new set of norms - considered to be more congruent with reform needs in transforming societies. The result is that, today, all nations of the world - with the possible exception of only South Korea - are treading the trajectory of a global transformation path toward a platform considered to be more suitable for achieving sustainable growth and equity. Second, contemporary transitional reforms has triggered a realignment of geopolitical influence and economic relations among nations, significantly enhanced cross-border flow and productivity of regional resources, and helped to create a new world order. As EMEs transform and steadily improve performance, they contribute a greater share to global productivity and economic growth, and drive up global competition for limited resources. Unlike global reforms of 1950s and 1960s which partitioned global resource flow along pro-market and anti-market coalitions and restrained resource flow and productivity, contemporary reforms have set in motion a healthier tendency, directed at shifting resource allocation rules from ideologically-determined needs to market-driven priorities. Third is the grassroots and institutionalization context of 
the reforms. Given the foundational reach and extent of events that triggered them, results attributable to current reforms have exhibited greater sustainability and have the potential to induce still more transformations in years and decades to come. Given their formative reach and fundamental robustness, the reforms address systemic questions pertaining to production and distribution systems and have become a reference point in economic history and literature for clarifying theoretical ideas and pragmatic issues pertaining to economic and social transitions. At such, knowledge accumulated from the studies done on them was helpful in forming the base ideas on which current research initiative is founded. Fourth, the transformations of the last three decades provide a historic opportunity to reflect and draw lessons for charting global course of future growth and development. One of the most instructive lessons learned is that, generally for any society, the entry point or development stage attained - prior to the launching of its reform institutionalization phase - does play a key role in shaping the overall reform progress and outcome. Generally, societies with pre-existing established infrastructures (i.e. law enforcement institutions, legislated property rights, banking and financial institutions, system of trade and commerce, transportation and communication networks, etc.) tend to have a stronger enabling environment for implementing and returning reform dividends, compared to societies that are deficient in them. Alternatively stated, the more developed a society's grassroots infrastructures are, the stronger the transformative capacity and the quicker its transitional turnaround; and conversely, the less developed the infrastructures, the weaker the absorptive capacity for reforms and the slower the turnaround potential. Thus, consequent of the unequal capacities and thresholds on which their reforms are founded, it is no surprise that Chinese and Pacific Asian reforms have produced steadier and more buoyant results while parallel reforms in Africa and Latin America are, for the most part, still buried in doldrums. In order for African and Latin American reforms to catch up with parallel reforms in Pacific Asia, they have to be established on stronger capacity-building fundamentals - the components of which were examined in the preceding sections of paper. Finally, answers to the five fundamental questions facing every economy (raised earlier in paper) are decided differently in different societies - given the unequal outcome of transitional reforms in different societies. Again, while developed economies and transitional societies in Pacific Asia have been able to answer the questions with definitive clarity - given the successful outcome of reform efforts in their regions, efforts to address same questions in Africa and other societies that are unwilling to execute needed reforms continue to face significant challenges.

\section{ACKNOWLEDGEMENT}

The author will like to acknowledge Stacey Bradshaw, Support Staff at Department of Agriculture, Virginia State University, for technical assistance with charts in this paper.

\section{AUTHOR BIOGRAPHY}

Dr. Richard Omotoye has published numerous articles in peer-reviewed journals and presented papers at several academic and business conferences. His research interests include transitional economies, financial transparency, agricultural entrepreneurship, development economics, and other related studies. He is a recipient of USDA grants and serves as Principal Investigator or Co-Principal Investigator in awarded USDA grants. Currently, he is an associate professor of economics at Virginia State University, Petersburg, Virginia, and serves as Coordinator of the Business and Economics program in the Department of Agriculture.

\section{REFERENCES}

Alam, A., Casero, P.A., Khan, F., Udomsaph, C. (2008). Unleashing prosperity: Productivity growth in Eastern Europe and the former Soviet Union. The International Bank for Reconstruction and Development/World Bank, Washington, D.C., 2008.

Andy X., (2013). Tale of two giants: China and India: Will Elephant, Dragon reform before crisis comes? Wall Street Journal Market Watch, September 9, 2013.

Awad, A. and Michael, R.E. (2010). IFLAS and Chapter 11: Classical Islamic law and modern bankruptcy. International Law, 44 (975).

Brue, Stanley L., et al., Economics: Principles, problems, and policies. 19th edition, McGraw-Hill/Irwin, 2011.

Devarajan, S., D., and Holmgren, T. (2001). Aid and Reform in Africa: Lessons from ten case studies. Washington, DC: World Bank. (C) World Bank. https://openknowledge.worldbank.org/handle/10986/13894 License: CC BY 3.0 IGO. 
Easterly, W. (2003). IMF and world bank structural adjustment programs and poverty. Chapter in NBER Book, Michael P. Dooley and Jeffrey A. Frankel (editors), Managing Currency Crises in Emerging Markets, (p.p. 361-392), University of Chicago Press.

European Bank for Reconstruction and Development (EBRD). (Annual Transition Reports).

Falcetti, E., Lysenko, T. and Sanfey, P. (2005). Reforms and growth in transition: Re-examining the evidence. Working Paper No. 90. London: European Bank for Reconstruction and Development.

Feige, E. L. The transition to a market economy in Russia: Property rights, mass privatization and stabilization. Chapter in Alexander, G. and G. Skapska, G. (editors), (1994). A forth way: Privatization, property and the emergence of new market economies. Routledge, New York, 57-78.

Frers, L.D., (2008). Why did the Washington Consensus Policies Fail? Center for International Private Enterprise (CIPE), Argentina, (CIPE archive document).

Gehlbach and Earle (2011). Why do similar reforms produce dissimilar outcomes?: Privatization Effectiveness in the shadow of Ukraine's Orange Revolution. 15th Annual Conference of The International Society for New Institutional Economics held at Stanford University - Stanford, CA, USA, June 16 - 18, 2011.

Gokarn, S. (2011). Economic reforms for sustainable growth. Presentation at the 175th annual general meeting of the Madras Chamber of Commerce and Industry, Chennai, 23 June, 2011.

Goldman, Marshall, (1994). Lost opportunity: Why economic reforms in Russia have not worked. New York, N.Y.: W.W. Norton \& Co.

Gregory Paul R., and Stuart C. (2001). Russian and Soviet economic performance and structure. Addison-Wesley Longman, 7th edition.

Heidhues, F. and Obare, G. (2011). Lessons from structural adjustment programs and their effects in Africa. Quarterly Journal of International Agriculture, 50, (1) 55-64.

Hermana, B., et al., (2012). E-government implementation in Indonesia: Financial transparency on the web. 3rd International Conference on e-Education, e-Business, e-Management and e-Learning, IPEDR Volume 27, IACSIT Press, Singapore.

International Monetary Fund (April, 2015). World Economic Outlook.

Lai, Q.B. (2000) Currency crisis in Thailand: The leading indicators. The Park Place Economist, Vol. 8.

Lin, Y.J. (2011). New structural economics: A framework for rethinking development. The World Bank Research Observer, $26(2)$

McHale, J. (2000). Brazil in the 1997-1999 financial turmoil-Fourth country meeting of the NBER Project on Exchange Rate Crises in Emerging Market Countries, April 14-15, 2000.

Missio, S. and Watzka, S. (2011). Financial contagion and the European debt crisis. CESIFO Working Paper No. 3554, August 2011.

Mitra, K. M. and Selowsky, M. (2002). Lessons from a decade of transition in Eastern Europe and the former Soviet Union. Finance and Development, 39(2), June 2002.

Mitra, P., Selowsky, M., et al (2002). Transition-The first ten years: Analysis and lessons for Eastern Europe and the former Soviet Union. World Bank Report, Washington, D.C.

Musacchio, A. (2012). Mexico's financial crisis of 1994-1995. Harvard Business School Working Paper, No. 12-101, May 2012.

Nsouli, Saleh M. (1999). A decade of transition: An overview of the achievements and challenges. Finance and Development, 36(2), June 1999.

Ogbu, O. (2012). The removal of oil price subsidy in Nigeria: Lessons in leadership and policymaking in a trust-deficit environment. Brookings Opinion Editorial, January 26, 2012.

Pastor, G and Damjanovic, T. (2011). The Russian Financial Crisis and its Consequences for Central Asia, IMF Working Paper, WP/01/169, October 2001.

Pearce, D. (2011). Financial inclusion in the Middle East and North Africa: Analysis and roadmap recommendations. World Bank Policy Research Working Paper Series, No. 5610.

Rajeev K.G. \& James W. S. (2016). Government decentralization and prevalence of the shadow economy. Public Finance Review, 44(2), 263-288.

Ravallion, M. (2008). Are there lessons for Africa from China's success against poverty? World Bank Policy Research Working Paper Series, No. 4426, January 1, 2008.

Rutherford, B. (2012). Progress in Zimbabwe: Shifting the debate on land reform, poverty and inequality in Zimbabwe-An engagement with Zimbabwe's land reform: Myths and realities. Journal of Contemporary African Studies, 30(1) (Special Issue).

Ryle, G. et al., (2013). Secret files expose off-shore's global impact, secret for sale: Inside the global offshore money maze. The International Journal of Investigative Journalists (IJIC), April 13, 2013.

Salami, R. \& Soltanzadeh, J. (2012). Comparative analysis for science, technology and innovation policy: Lessons learned from some selected countries (Brazil, India, China, South Korea and South Africa) for other LDCs like Iran. Journal of Technology Management \& Innovation, 7(1) 211-227.

Smith, A. An inquiry into the nature and causes of the wealth of nations. London: Methuen and Co., Ltd., ed. Edwin Cannan, 1904. Fifth edition. 
Transparency International, (2009). The business case against corruption: Clean business is good business. A joint publication by International Chamber of Commerce, Transparency International, UN Global Compact, World Economic Forum Partnering Against Corruption Initiative (PACI).

World Bank, (2013). China 2030: Building a modern, harmonious, and creative society. A joint report by the World Bank and the Development Research Center of the State Council of the People's Republic of China. Washington, D.C., May 22, 2013.

World Bank, (2013). World Development Report. 